\title{
The Conception of National Insights in Islamic Perspective
}

DOI: https://doi.org/10.47175/rissj.v1i3.111

\section{| Koko Adya Winata ${ }^{1^{*}}$ | Tatang Sudrajat ${ }^{2}$ | Muhibbin Syah ${ }^{3}$ | | Asep Nursobah ${ }^{4}$ |}

\author{
1,2Universitas Sangga \\ Buana, Indonesia \\ 3,4 UIN Sunan Gunung Djati, \\ Indonesia
}

*adyawinata@gmail.com

\begin{abstract}
This article aims to explain the concept of national insight from an Islamic perspective. This research uses a descriptive qualitative method by collecting data through observation, documentation, and literature review. Based on the research results, the concept of national insight has been regulated and explained in Islamic teachings. National insight is a person's view of a national entity based on certain territorial boundaries that affect his attitude towards love for his homeland. As a religion of Rahmat Lil Alamin, Islam clearly states about human life formed in a diverse civilization, both in culture, ethnicity, religion, and Nation. Nationality is a reality of human civilization recognized in Islamic teachings as part of Allah's will in creating humans. The results of the research conclude: 1) The reality of the creation of human beings with nationalities and tribes is a necessity which is mentioned in the Koran, 2) The concept of nationality does not contradict Islamic teachings, 2) The Medina Constitution is a concept of a state carried out by the Prophet and Muslims who are in harmony with national values.

KEYWORDS

Conception; national insight; Islamic Perspective
\end{abstract}

\section{INTRODUCTION}

The concept of nationality is formed due to the same history, the same cultural character, and the people who live in an area relatively close to the same cultural roots and customs. As a country, Indonesia is formed based on the national consciousness of its inhabitants who have historically experienced the same fate, namely becoming a colonial area of other nations. The desire to escape from the grip of colonialism has given birth to a national consciousness that ignores regional interests. The Indonesian Nation's birth is closely related to the conditions and development of the world, Where in the 20th century. The people in Asia realized the importance of independence. So that the will to become an independent and sovereign people has encouraged the birth of ordinary thought and action, namely driving out the invaders. The awareness to break away from colonialism has given birth to the crystallization of thoughts and actions in national consciousness. This national insight and attitude is a manifestation of the same awareness that expelling the invaders cannot be done regionally but must be together with the term the rise of nationalism (nationality).

The shared awareness to expel the invaders led to the birth of an initially a regional movement with a national concept. Initially, primordial, ethnic, and regional movements of resistance to colonialists turned into nationalist resistance. This nationalist movement is alleged and believed to have led the Indonesian Nation to become a colonized nation initially into an independent and sovereign nation, which was proclaimed on August 17, 1945. The birth of the Indonesian Nation cannot be separated from the world's 
development at the beginning of the 20th century. At that time, the people of Asia began to realize that they, who were colonized by Western nations, also had the right to be recognized as a nation. What happened in Indonesia was that on May 20, 1908, the Boedi Oetomo organization was established, spearheaded by dr. Wahidin Soediro Hoesodo, a milestone in the starting point for the formation of awareness as the Indonesian Nation. The Indonesian people annually commemorate this date as National Awakening Day (May 20, 1908) (Basseng, dkk, 2019: 11). The resistance movement of the kyai and the Muslims with a national spirit in driving out colonialism has led the Indonesian Nation to become an independent and sovereign nation. Islam has been very clear about the teachings that uphold humanity, justice, civility, and freedom. Occupation is not in line with Islamic teachings, and everyone is obliged to fight against any form of colonization. So that the resistance movements against colonialism, even though at first they were still regional in nature, we're driven by many ulama (Islamic religious leaders) who became evidence that colonialism was not under Islamic teachings. As the religion of revelation in its teachings, Islam teaches about the concept of regulating society and managing a state that upholds independence, justice, and civility. The Koran also clearly states that Allah SWT has created humans who consist of various tribes and nations to know each other. So that the concept of nationality is mentioned in the Koran. As evidence of the legalization of the concept of nationality from the perspective of Islamic law.

The concept of nationality in Islam's perspective is the same as a nationality in the sense of nationalism, which is an attitude to build a just human civilization and uphold human dignity. Islam and nationality are often opposed. And seen as two concepts with different thinking grounds. According to some Islamic activists, society must be in the Islamic state with a caliphate system. To regulate and manage human life must be in the concept of Daulah Islamiyah. Religion and politics run in one place under the control of the Caliph or imam. The Caliph or Imam is not only the person who carries out the mandate of the people, but also the divine mandate because the real holder of sovereignty is God who delegates his authority to the Caliph. Thus, the Khilafah system is often claimed to be a divine rule that must be enforced on earth to replace the concept of nationhood. A state based on the concept of nationality is not by Islamic teachings, because what is by Islam is Daulah Islamiyah with a caliphate system. It is as if the Islamic and nationality discourse solutions will never be reconciled about the assumption that the Khilafah and nationality have different roots of thought. However, the study of Islam and nationality must still be discussed so that this disparity in understanding does not cause conflict. This article is hoped to contribute and think about solutions to the dichotomy of Islam and nationality.

\section{RESEARCH METHODS}

The method used in this research is a descriptive qualitative approach. Qualitative research aims to analyze how the concept of national insight from an Islamic perspective. The researcher seeks to describe nationalism and how Islam, as a revealed religion views the concept of nationality. By using the literature method, researchers can collect data through studies of journals, articles, books, and scientific writings on the internet related to the concept of national insight from an Islamic perspective. Through a qualitative approach, researchers can more freely observe, understand, and analyze nationality from the Islamic perspective. 


\section{RESULTS AND DISCUSSION \\ Definition of National Insight}

National insight is formed naturally in connection with the shared awareness of the inhabitants of an area of the history and the attitude of togetherness to face a future full of challenges in the global arena. National insight comes from the word insight and nationality. Insight means the ability to understand or perceive a particular concept, which is reflected in individual behavior under the concepts or main thoughts contained therein. Meanwhile, nationality is an attitude, awareness, or attitude that views the notion that one is part of the same national group with mutually agreed upon socio-cultural attachments (Supriyadi Ahmad :2017, 45).

According to Otto Bauer, the definition of a nation focuses more on the character or temperament of a group of people who become the identity $\mathrm{f}$ a nation. This character will be reflected in the attitude of citizen-nation behavior. This character is the hallmark of a nation that differentiates it from other nations, which is formed based on the historical experience of the Nation's culture, which grew and developed along with the NationNation's development. Nationality means (1) the characteristics that mark the national class, (2) regarding the Nation; concerning (related to) the Nation, (3) selfawareness as citizens of a country. 3 (Wantanas, 2018: 46). The concept of national insight refers to three things, namely national understanding, a sense of nationality, and national spirit. The national perspective is a way of seeing the Indonesian Nation towards itself and its environment based on Pancasila, the 1945 Constitution, Unity in Diversity and the Republic of Indonesia (Windy Kartika Putri Widayanti, Armaidy Armawi, Budi Andayani, $2018: 5)$.

\section{The Birth of the National Insight}

The concept of national insight is born due to the similarity that society feels about the conditions that occur in itself and the surrounding environment. A sense of nationality will emerge to the surface and become the spirit of togetherness of a society that will be deeply rooted in its life due to several things:

\section{The Similarity of Will}

The concept of nationality arises because citizens have the same desires and interests to be realized in their lives. According to Ernest Renan, a Nation is a group of people who have the will to unite to feel they are one (le desir d'etr ensemble). The will to unite is the forerunner to the formation of nationality. Thus, the main factor that shapes the spirit of nationality is the desire and will of the citizens to form a nation and a state that can be a common foundation in carrying out life. The spirit to have awareness and be willing to unite in the interests of the future is the essence of a nation, giving rise to a common ideal of having one inseparable unity (Aditya Prawira1 and Isa Maryati, 2019: 3).

\section{Cultural Similarities}

National awareness can occur due to the similarity culture and customs in a society, each of which agrees to unite itself in the spirit of nationality. Culture is the result of the interaction of life together. Humans, as members of society, are constantly experiencing changes (Muhammad Bahar Akkase Teng, 2017: 75). Culture has a function that can unite groups in society to form larger groups as a manifestation of a national attitude's birth. The same culture will make it easier for each group to communicate and interact, which can unite attitudes in achieving broader interests deemed necessary. The cultural similarity is 
one factor that can generate mutual awareness where each group will unite itself to the concept of nationality.

\section{Historical Similarities}

The national spirit was born due to the similarity in history where each existing entity requires a unified attitude to achieve interests that are seen as the same. Due to historical similarities, the national spirit was the rise of the resistance struggle against the colonialists. Like the struggle for Indonesian independence, which was initially regional, then became national in nature. Nationalism in the history of the struggle for Indonesian independence has raised the strength of the struggle against oppression carried out by the colonialists for hundreds of years.

The feeling of similarity and acceptance that is experienced can overcome the differences in ethnicity and culture. The similarity of history has been able to give birth to the idea of nationality to expel invaders. The idea of nationality was born from anticolonialism and imperialism sentiment, which aims to raise awareness of the importance of a nation's independence ( Masroer, 2017: 235).

\section{Regional Similarities}

The emergence of a sense of nationality is due to the territorial similarities inhabited by certain people groups. Regional equality has encouraged each of its inhabitants to unite themselves in a broader concept of togetherness called nationality. People who occupy certain areas will relatively have emotional ties that can unite views in determining and achieving more significant common interests. The awareness to knit the bonds of togetherness of every resident in an area by expressing an attitude to unite himself is called nationality. What marks the existence of a nation is the existence of a regional unity as a living space ( Bali Widodo, 2019:16).

\section{Islam and Nationality}

Islam and nationality are often confronted by some circles as if they contradict each other, which cannot possibly be united. The concept of nationality is seen as incompatible with Islamic teachings because it regulates human life, not with a national state but with the Islamic daulah.

\section{Arabiyyun and 'Ajamiyyun}

The terms Arabiyyun and Ajamiyyun were put forward by the Prophet Muhammad SAW when he gave a sermon during the Hajj Wada. The message contained in the sermon is universal, namely explaining civilization and humans' virtues, both Arab and non-Arab. The mention of Arab and Non-Arab territories (Ajam) is an essential sign that Islam was not intended to bring about human civilization, but Islam as a religion that can respect various national cultures that are different from Arab culture. The Prophet mentioned the word Ajamiyyun as strong evidence of recognition of nations other than Arabs because of human position, not because of the origin of their Nation. Arabs are people who live in a particular place and already have civilization and culture. Arabs existed long before Islam was born there. They are known to have an established civilization. They inhabit the Arabian Peninsula, a desert area that stretches from west of the Sahara in Africa to the east across Asia, Central Iran, and the Gobi Desert in China (Muhamad Mustaqim and Muhamad Miftah, 2015: 87). Some experts say that Arab civilization's aspects include religion, politics, economics, and cultural arts. The origin of the Arab population, according to Muslim historians, is divided into three categories, namely: 1) al-'Arab al- 
Ba'idah: Old Arabic; 2) 'Arab al-Arabiyah: Indigenous Arabs; and 3) al'Arab alMusta'ribah: Arab immigrants (Yuangga Kurnia Yahya, 2019:44).

The hadith of the Prophet which mentions Arabic and non-Arabic terms reads as follows

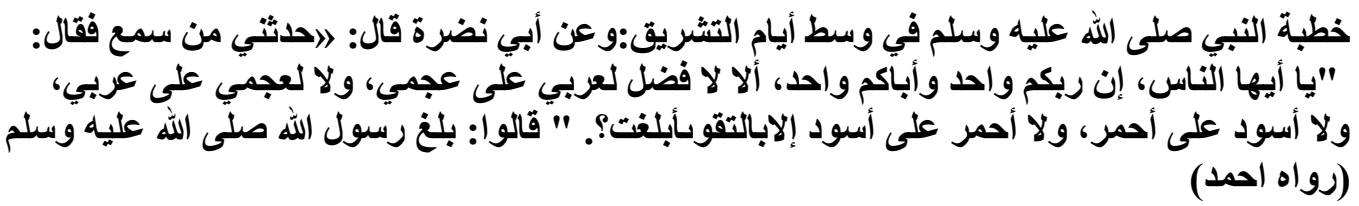

Meaning: "From Abu Nadhrah has told me, people who have heard the sermon of the Prophet Muhammad in the middle of the day of Tasyriq, he said:" O people! Your Rabb is one, and your father is one (meaning Prophet Adam). Keep in mind. There is no advantage for an Arab over an Ajam (non-Arab) person and for an Ajam person over an Arab person, for a red person over a black person, for a black person over a red person except with piety. Have I delivered?" they answered: Yes, it is true that Rasulullah SAW had delivered. "

According to the hadith above, the Prophet explicitly gave a universal message regarding human life, namely:

a. The mention of Arabic and Ajam is proof that the teachings of Islam are not only for Arabs but for all people in the world ('Ajam).

b. Humans' virtue is not due to the origin of their ancestors, not because of the place where they were born and not because of their skin color and language but because of their devotion. Even if an Arab is not cautious, his Arab origin does not lead to virtue.

c. The terms Arabiyyun and Ajamiyyun simultaneously indicate the concept of nationality in which every Nation, both Arab and non-Arab, can carry out its life by practicing Islamic values without having to be sanctioned.

d. The concept of nationality does not contradict Islamic teachings because the nature of Islamic teachings is not to make the world an Arab culture but a world civilization that upholds piety's values .

e. Arabic and Ajam are terms for a group of people who live and live in a specific area with the awareness to live together. Similarity in territory and culture of the inhabitants who wish to unite themselves in living together is called the spirit of nationality.

\section{Piagam Madinah (Madinah Charter)}

Muslims began to live as a state under the Prophet Muhammad SAW's leadership since he moved to the Yathrib area (Medina) and later became the center of his government. The life of a state that was carried out by the Muslims at that time was egalitarian, inclusive, and aspirational. As the leader of the state and government, the Prophet has established a national community that has a common goal of building a just country with a heterogeneous community background. It was in Medina that a community of nations was born who lived together with one goal to build a country based on a pluralistic life. Life in Medina shows plurality both in terms of religion (there are Muslim and non-Muslim groups) and groups. Namely the Ansar (followers of the Prophet who came from Medina) and Muhajirin (the Prophet's followers from Mecca). After settling in Medina, the Holy Prophet then formulated and announced the Medina Charter. (Moh Dahlan, 2014: 6).

The fundamental principles of the Medina charter have inspired the formation of the modern state. So that the Prophet Muhammad SAW deserves to be called the pioneer of a 
modern-minded and advanced country, these principles are: The Medina Charter is a charter born from a social contract between Muslims, Jews, and Christians.

a. The Constitution of Medina became the foundation of the Prophet's state, which stipulated his rules so that every community, both Muslim and non-Muslim, and various ethnic groups and tribes, could unite to create a just state.

b. The Medina Constitution has become a nation-state concept that describes pluralism as a nation that must live in harmony and side by side to create a dignified human civilization.

c. Medina Charter is a constitution that has laid the socio-political foundations for the people of Medina in a government under the leadership of the Prophet Muhammad.

d. The principle of state life established by the Prophet was egalitarian and inclusive.

Prophet Muhammad SAW has succeeded in building a just society under the constitution of Medina. Political experts consider the Medina Charter as the first Basic Law in an Islamic state established by the Prophet Muhammad. 13 (Imam Amrusi Jailani, 2016: 272). With the constitution of Medina, the Holy Prophet in a short time, succeeded in putting universal and inclusive principles to form a nation-state that had never been united before, was able to build cities that would become centers of world civilization, and bring holy books which were the source of knowledge, policy. And faith. The Holy Prophet built brotherhood among citizens and the Nation in Medina based on the Medina Charter. Based on the Medina Constitution, the Muslims and other communities can coexist in realizing a dignified human civilization. Prophet Muhammad, under the Medina Charter (Madinah Charter) or Shahîfat al-Madînah, has practiced a democratic society and state life in a plural society with heterogeneous ideological and political flows. The Medina Constitution is the foundation stone of a country with a national concept. At that time, the Prophet Muhammad SAW, with his prophetic and apostolates, had shown him to be a true statesman who protected all circles. The state is not explicitly based on Daulah Islamiyah but is based on the Medina Charter.

The Constitution of Medina embraces a nation-state that practices universal Islamic values such as justice, humanity, civility, and human honor. The leadership type of the Prophet Muhammad SAW was very democratic and tolerant of all parties. The leadership of the Prophet has made all residents feel safe and secure. In the end, the city of Yathrib turned into Madinah Al-Munawarah, which means a city of light.

According to Munawir Syazali the basic principles of the Medina Charter are as follows: (Bukhari Abdul Shomad, 2013: 56).

a. All Muslims, although they come from many tribes, is one community.

b. The relationship between members of the Islamic community and other community members is based on principles; good neighbors help each other face common enemies.

c. Defend those who are persecuted

d. Mutually advising and respecting freedom of religion.

\section{Colonial Age Islamic Movement}

When the Dutch entered the archipelago (1596), there were already difficulties in facing the Muslim community. Dutch colonialism always faced intense resistance from people who embraced Islam, such as Banten's battle, Hasanuddin in Makassar, the Diponegoro war, the Padri war, the Aceh war, and so on (Duriana, 2015: 58).

The resistance of the Kyai, which was regional in nature, was very easily defeated by the invaders. The successive defeat against the invaders has awakened the awareness of the Kyai to fight against the invaders together. Awareness of the Kyai in expelling the invaders 
together is the forerunner to a national spirit's birth. As a religion of Rahmat Lil Alamin, Islam not only regulates how the ritual process of worship is carried out by its adherents but also regulates the social order patterns. The Muslims in the colonial era had proven themselves as an ummah who were not only obedient in matters of Mahdoh worship, as evidenced by the emergence of a spirit of movement and resistance to expel the invaders. The Kyai and the Muslims' resistance movement to expel the invaders has risen everywhere with the spirit of jihad fi Sabilillah. Various resistance to the Dutch government such as the Paderi War (1821-1827), the Diponegoro War (1825-1830), and the Aceh War (1873-1903) could not be separated from the teachings of Islam. Resistance was spearheaded by the scholars who had returned from Mecca. Or at least from those who had been influenced by the pilgrims (Sitti Aisyah, 2015:122).

The Muslims' resistance to expelling the colonialists was initially still regional in nature so that they were unable to expel the Dutch colonial colonialists. The Islamic movement, which was regional in nature, did not produce results and was always defeated by the colonizers' colonialism policies. Then there arose an awareness of the Kyai to stand together against the invaders. Who was initially been regional in nature to change together? This shared awareness to drive out invaders is what is called the spirit of nationality.

The struggles that were carried out regionally so far, such as the Diponegoro War, the Padri War, the Aceh War, the Hasanuddin battle, and others, were deemed ineffective in repelling the Dutch colonialists. Because it is necessary to formulate a force that binds the potential that exists throughout the country, this kind of awareness is known as national consciousness, namely awareness that raises the spirit of nationality. Success in breaking away from the colonialists through the nationalist movement is an attitude that must be appreciated and maintained. The nationalist movement in the colonial era was a model of resistance shared in facing the colonialism of other nations to achieve independence and justice. In principle, the concept of nationhood in the colonial era was more of a collective effort to escape the shackles of colonialization to achieve sovereignty, justice, humanity, and independence as taught in Islam.

\section{Basic National Values}

The fundamental values fought for in the spirit of nationality are by Islamic teachings. Awareness of each group, tribe, and region to live together under the rules. That has been agreed upon is known as the concept of nationality. Awareness and understanding to live together in the spirit of nationality aim to achieve common interests, namely:

\section{Humanity}

Humanity is a universal attitude that all parties must have and fight for, so that life's continuity does not harm human values and dignity. Cruelty, colonialism, and oppression and seeing certain ethnic groups or nations as higher in position, are very contrary to the concept of humanity. The birth of a national spirit is understood to protect human values. The struggle that prioritizes ethnicity is seen as having obstacles to protect human values and the emergence of tribalism that considers itself the most superior. The existence of colonialism in the past and neo-colonialism with its new formation represents the threat of human values. Human values (Human Values) consist of five pillars, namely Truth, Virtue, Peace, Compassion, and Nonviolence. (Art-Ong Jumsai Na Ayudhya. 2008). Upholding and protecting humanity is in line with Islamic teachings. The imperative to protect human dignity can be seen from the Koran prohibitions that can injure humanity, such as insulting, mocking, making fun of, and calling others by lowering their dignity. 


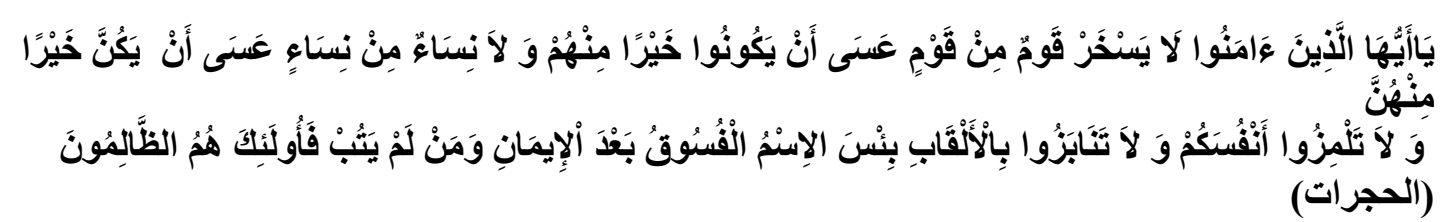

Meaning: "Hi people who believe, do not one people criticize other people (because). They may be better than them (those who criticize) and not women (criticize) other women (because). It may be that a woman (who is reproached) is better than a woman (who is criticizing) and do not criticize yourself and do not call yourself a lousy title. The worst calling is a bad (calling) after faith. And whoever is not repent, then they are the ones who do wrong. "(Surah al-Hujurat, 49:11).

\section{Justice}

The national spirit is born because of a mutual agreement to uphold the values of justice in life. Justice is a basic national value that must be guaranteed its implementation. First, equality is seen as an element of justice. In which universal values are contained and that justice, on the one hand, can be interpreted as the same as law, this can be seen from the term "justice" which means law, but on the other hand, justice is also an objective. Law. In achieving this goal, justice is seen as impartiality. This attitude contains the idea of equality, which is the equality of treating everyone fairly. Second, equality is a right; equality as a right can be seen from the provisions of The Universal Declaration of Human Rights 1948. as well as in the International Covenant on Economic, Social and Cultural Rights 1966 and the International Covenant on Civil and Political Rights 1966 (Bahder Johan Nasution, 2014: 124). In Islamic teachings, the concept of justice is emphasized as follows:

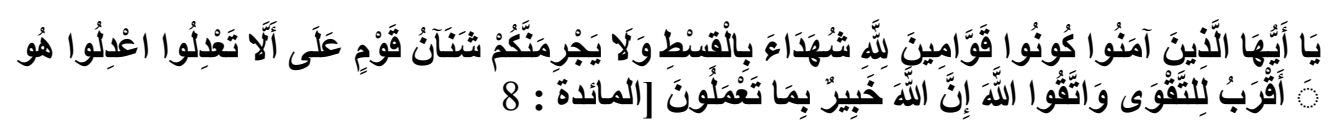

It means: "O you who believe, let you be the ones who always uphold (the truth) for the sake of Allah, be witnesses legally. And do not you ever hate people, encourage you to be unfair. Be fair, because fair is closer to taqwa, fear Allah, Allah knows best you are doing. "(Qs. Al Maidah: 8).

\section{Democracy}

Democracy is a primary national value that becomes a tool for determining joint decisions of each different group's interests. Through a democratic deliberation process, every decision will be determined. Decisions that are binding on all parties will be determined by deliberation. Democracy is one of the primary national values that will unite various interests. In Islamic teachings, it is explained the importance of deliberation in every decision making. The democracy mandated in Islam is different from democracy in western terminology. Western democracy emphasizes power in the hands of the people; Islamic democracy teaches that power is in God's hands. The democratic value referred to in Islamic teachings relates to the necessity to conduct deliberation in every decision making. This is confirmed in the Koran:

$$
\text { في الأمر وشاور هم فإذا عزمت فتوكل على اللّ }
$$

And consult with them in this matter, then you have made up your mind, then put your trust in Allah. Indeed, Allah loves those who put their trust in Him "[Ali-Imran / 3: 159].

\section{Plurality}

Plural society is a social reality that must be understood and understood by all components of society. The primary value of nationality is to recognize and respect the diversity that 
exists in society. Awareness of plurality must be socialized and circulated to the whole community so that the building of tolerance and togetherness amidst diversity can be maintained. Recognition and respect for the diversity of identities is the basis that must be taught to humans in the framework of creating a harmonious life. Islamic teachings very clearly teach about the diversity in society must coexist and respect each other. Order and justice created in human life are the goals and ideals of Islamic teachings. Islam teaches about how to build togetherness, justice, mutual respect, and tolerance amid diversity (Koko Adya Winata, Uus Ruswandi, Mohamad Erihadiana, 2020: 52). The verses of the Koran that explain diversity in life are contained in surah Al Hujurat verse 13.

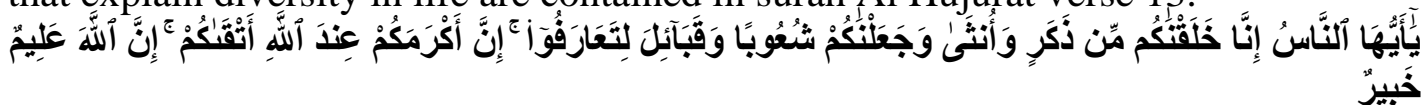

Meaning: "O people, we created you from a man and a woman and made you nations and tribes to know each other. Unquestionably the noblest among you in the sight of Allah is the most devout among you. Allah is All-Knowing, All-Knowing ". (QS; Al Hujurat: 13).

\section{National Integration}

National integration is the national spirit possessed by each group of people who have united themselves to live together to maintain unity and integrity. Shared interests and integrity always take priority over group interests. The spirit of maintaining unity is an essential factor in the concept of nationality.

\section{CONCLUSION}

Islam and nationality are often opposed. And seen as two concepts with different thinking grounds. According to some Islamic activists, society must be in the Islamic state with a caliphate system. To regulate and manage human life must be in the concept of Daulah Islamiyah. Religion and politics run in one place under the control of the Caliph or imam. The Caliph or Imam is not only the person who carries out the mandate of the people, but also the divine mandate because the real holder of sovereignty is God who delegates his authority to the Caliph. Thus, the Khilafah system is often claimed to be a divine rule that must be enforced on earth to replace the concept of nationhood. Understanding of Islam and nationality can be seen from the state and government processes carried out by the Muslims under the Prophet Muhammad as the head of state and government based on the Medina Charter. The Medina Constitution is the foundation of the Prophet's state, which stipulates the basic rules so that every community, both Muslim and non-Muslim, as well as various tribes and tribes, can unite to create a just state. The Medina Charter is a charter that was born from a social contract between Muslims, Jews, and Christians.

\section{REFERENCES}

Art-Ong Jumsai Na Ayudhya. (2008). Integrated Human Values Learning Model:An Effective Approach to Develop Human Values or Character in Students. (Jakarta: Sathya Sai Indonesia Education Foundation, 2008).

Aditya Prawira and Isa Maryati. (2019). Analysis Of High School History Grade XI Using Ernest Renan's Nationalism Approach (Historica Vol. 22 No. 2 October 2019), 1-20.

Basseng, et al. (2019). Insight Of Nation And State Values, (Jakarta: State Administration Institute of the Republic of Indonesia, 2019) 
Baader Johan Nasution. (2014). Philosophical Study On The Concept Of Justice From Classic Thinking To Modern Thoughts, (Yustisia Vol. May 3 No.2 - August 2014), 118130.

Bali Widodo. (2019). Building a Religious National insight for the sake of Creating.National

Integration through Citizenship Education, (JPK Pancasila and Citizenship Journal, Vol. 4, No.3 of 2019), 13-24.

Duriana. (2015). Islam in Indonesia Before Independence, (Dialectics, Vol. 9, No. 2, January December 2015), 57-70.

Imam Amrusi Jailani. (2016). Charter of Madinah: Philosophical Foundation Democratic State Constitution (Al-Daulah: Journal of Islamic Law and Regulation Volume 6, Number 2, October 2016); ISSN 2089-0109, 269-295.

Koko Adya Winata, Uus Ruswandi, Mohamad Erihadiana. (2020). Konsepsi Islamic

Education on Multicultural Principles in School, Atta' dib Journal of Islamic Religious Education, PAI Study Program, TarbiyahIAIN Faculty Bone, Vol. 1, No.1, June 2020), 52

Masroer. (2017). The Ideas of Indonesian Nationalism as a Country Bangsa dan Relevance with the Indonesian Constitution (Sociology of Religion: Scientific Journal of the Sociology of Religion and Social Change, Vol. 11, No. 2, July-December 2017), ISSN: 1978-4457 (p), 2548-477X (o), 229- 238.

Moh Dahlan. (2014). Relationships and State in Indonesia, (Analysis: Journal of Islamic Studies, Volume 14, Number 1, June 2014), 1-28.

Muhammad Bahar Akkase Teng, (2017), Philosophy of Culture and Literature (In Historical Perspective) (Journal of Cultural Science Volume 5, Number 1, June 2017), ISSN 2354-7294, 69-75.

Muhamad Mustaqim and Muhamad Miftah, (2015), The Challenge of the State Nation (Nation-State) in Facing Islamic Fundamentalism (Addin, Vol. 9, No. 1, February 2015), 85-106.

Sitti Aisyah. (2015). Dynamics Of Indonesian Islamic Community in Thecolonial Period Belanda (Historical Review), (Rihlah Journal Vol. II No. 1 May 2015), 120-127.

Supriyadi Ahmad. (2017), Transformation of Pancasila Education and National Insight For Millennial Generation for Anti-Corruption Revitalization, (Salam: Syar-i Social and Cultural Journal. Volume 4 No.1, 2017). ISSN: 2356-1459, 43-56.

Wantahnas, (2008). Main Module of National Defense Development, Module 1: Conception of State Defense and Module 2: Implementation of State Defense (Jakarta: Indonesian National Resilience Council, 2008).

Windy Kartika Putri Widayanti, Armaidy Armawi, Budi Andayani, (2018), InsightsSenior High School Student Nationality and Its Implications for Student Personal Resilience, (Jurnal National Resilience Vol. 24, No.1, April 2018), 1-26.

Yuangga Kurnia Yahya. (2019). The Influence of the Spread of Islam in the Middle East and Africa North: Geobudaya and Geopolitical studies, (Al-Tsaqafa: Journal of Islamic Civilization Vol. 16 No.1, June 2019), 044-062. 